\title{
The relative contribution of layers of the Social Ecological Model to childhood obesity
}

\author{
Punam Ohri-Vachaspati ${ }^{1}{ }^{*}$, Derek Delia ${ }^{2}$, Robin S DeWeese ${ }^{1}$, Noe C Crespo $^{1}$, \\ Michael Todd ${ }^{3}$ and Michael J Yedidia ${ }^{2}$ \\ 'School of Nutrition and Health Promotion, Arizona State University, 500 N 3rd Street, Phoenix, AZ 85004-2135, \\ USA: ${ }^{2}$ Center for State Health Policy, Institute for Health, Health Care Policy, \& Aging Research, Rutgers University, \\ New Brunswick, NJ, USA: ${ }^{3}$ College of Nursing and Health Innovation, Arizona State University, Phoenix, AZ, USA
}

Submitted 1 November 2013: Final revision received 8 July 2014: Accepted 19 September 2014: First published online 6 November 2014

\begin{abstract}
Objective: The Social Ecological Model (SEM) has been used to describe the aetiology of childhood obesity and to develop a framework for prevention. The current paper applies the SEM to data collected at multiple levels, representing different layers of the SEM, and examines the unique and relative contribution of each layer to children's weight status.

Design: Cross-sectional survey of randomly selected households with children living in low-income diverse communities.

Setting: A telephone survey conducted in 2009-2010 collected information on parental perceptions of their neighbourhoods, and household, parent and child demographic characteristics. Parents provided measured height and weight data for their children. Geocoded data were used to calculate proximity of a child's residence to food and physical activity outlets.

Subjects: Analysis based on 560 children whose parents participated in the survey and provided measured heights and weights.

Results: Multiple logistic regression models were estimated to determine the joint contribution of elements within each layer of the SEM as well as the relative contribution of each layer. Layers of the SEM representing parental perceptions of their neighbourhoods, parent demographics and neighbourhood characteristics made the strongest contributions to predicting whether a child was overweight or obese. Layers of the SEM representing food and physical activity environments made smaller, but still significant, contributions to predicting children's weight status.

Conclusions: The approach used herein supports using the SEM for predicting child weight status and uncovers some of the most promising domains and strategies for childhood obesity prevention that can be used for designing interventions.
\end{abstract}

\section{Keywords Social Ecological Model Childhood obesity}

The Institute of Medicine's 2005 report, Preventing Childhood Obesity: Health in the Balance, used the Social Ecological Model (SEM) to describe the possible aetiology of the childhood obesity epidemic and also to lay the groundwork for future interventions ${ }^{(1)}$. Based on ecological systems theory, the SEM postulates that changes in individual outcomes are influenced not only by individuallevel factors such as age and gender, but also by interactions with the larger social, cultural, economic and environmental contexts in which individuals live ${ }^{(2,3)}$. Appropriately, the SEM, which posits concentric layers of influence including intrapersonal, interpersonal, community, organization, government, industry and societal domains, is a frequently used model in childhood obesity research and prevention efforts $^{(4-6)}$.
Researchers have investigated individual factors within different layers of the SEM to understand the influence of these factors on children's weight status. Child-level factors such as age, race and gender ${ }^{(7,8)}$, parental characteristics such as weight status and education level ${ }^{(8-10)}$ and household characteristics such as income ${ }^{(11)}$ have consistently been associated with children's weight status. Community-level factors such as proximity to types of food outlets and physical activity (PA) facilities, however, have produced mixed findings ${ }^{(12-25)}$.

Although prior studies have examined specific elements of the SEM, important unanswered questions remain about the combined contribution of elements in each layer. Such an analysis is crucial for setting priorities among different intervention domains and allocating scarce resources. 


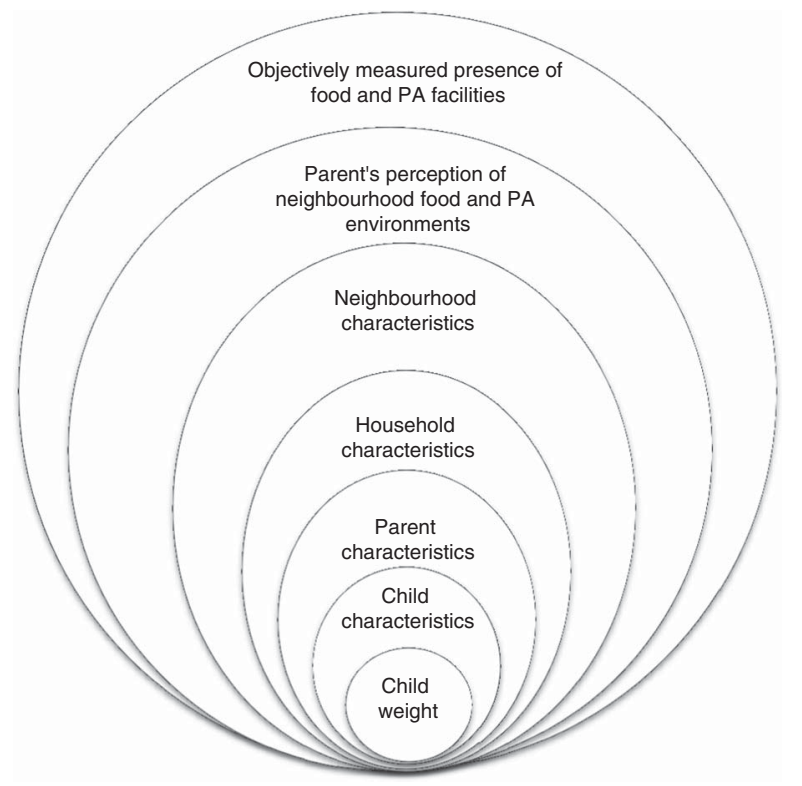

Fig. 1 Social Ecological Model showing the layers influencing a child's weight status (PA, physical activity)

For example, studies often investigate the independent contribution of one or more elements of the community built environment (e.g. parks, stores) ${ }^{(16,25,26)}$, but seldom quantify the combined contribution of various elements of the built environment taken together on children's weight status. Neglecting the combined contribution of elements within the same SEM layer can be problematic if those elements correlate highly with each other, creating a situation in which each individual element appears to contribute negligibly to weight outcomes although the elements taken together are highly predictive. Similarly, prior studies seldom account for the combined contribution of each SEM layer independent of contributions attributable to other layers. For example, in analyses where models are built incrementally, estimates of the contribution of variables entered in the first step (e.g. individual-level sociodemographic variables) do not reflect or account for contributions from subsequent layers (e.g. community-level demographics, built environment variables) ${ }^{(9,27)}$. Thus examination of the independent and relative contribution of each layer of the SEM - information that can be valuable in designing interventions and setting priorities - is not possible. To address these unanswered questions, the analysis presented here uses data collected from low-income, high-minority communities as part of the New Jersey Childhood Obesity Study. The study collected comprehensive information on children's BMI and multiple layers of the SEM (Fig. 1), including child-, parent-, household- and neighbourhood-level characteristics, parental perceptions of the food and PA environments and objective measures of community food and PA environments, to examine the unique and relative contribution of different layers on children's weight status.

\section{Methods}

\section{Data sources}

Housebold survey

Data were collected in 2009-2010 from a random-digit-dial sample of 1408 households in four low-income cities in the state of New Jersey in the USA. Households with a landline telephone and at least one child in the age range of 3-18 years old were included. Participants were offered an incentive of \$US 10 for completing the survey, which was conducted in either English or Spanish. The respondent was the adult 'parent' who made most of the decisions about food shopping for the household. The overall survey response rate ${ }^{(28)}$ for the survey was $49 \%$.

Survey items used for the present analysis were derived from previous research as described in Table 1. At the conclusion of the survey, parents were asked to weigh and measure themselves and their children using instructions based on the Centers for Disease Control and Prevention's guidelines and a tape measure mailed to their homes. The instructions also included suggestions on locating weighing scales in the community (e.g. doctor's office, community centre, WIC (Special Supplemental Nutrition Program for Women, Infants, and Children) clinic, YMCA) in case parents did not have a scale at home. Parent-measured heights and weights were mailed back to the researchers on a reporting worksheet. An additional \$US 10 incentive was offered for completion of this task; $40.5 \%$ of participants who provided their mailing addresses returned completed worksheets. Parent-measured heights and weights have been reported to be highly correlated with professionally measured values ${ }^{(29)}$ and more accurate than parent-reported estimates ${ }^{(30)}$.

\section{Neighbourhood demographic data}

Indicators of neighbourhood socio-economic conditions, calculated at the census block group level, were derived from pooled 2005-2009 American Community Survey data ${ }^{(31)}$.

\section{Geographical information systems data}

Drawing on commercial and publically available data sources, objective geocoded data on locations of food outlets and PA facilities in each of the study cities as well as in a $1.61 \mathrm{~km}$ ( 1 mile) buffer around the city boundary were collected. Food outlet data were purchased from two commercial vendors, InfoUSA and Trade Dimensions, and using methodology developed by Ohri-Vachaspati et $a l .{ }^{(32)}$ were categorized into supermarkets, small grocery stores and specialty stores, convenience stores and fast-food restaurants.

Similar data on private and public PA facilities and parks were collected, using a methodology proposed by Abercrombie et al. ${ }^{(33)}$. This strategy included acquisition of data from county and city departments, web-based searches and the Yellow Pages. Only parks larger than 0.40 ha 
Table 1 Definitions and descriptions of variables included in the analysis grouped by layers of the Social Ecological Model

\begin{tabular}{|c|c|c|}
\hline Variable name & Definition and description & Variable codes and categories \\
\hline \multicolumn{3}{|l|}{ Child demographics } \\
\hline Age & Child's age divided into three categories & $\begin{array}{l}3-5 \text { years }(\text { ref.) } \\
6-11 \text { years } \\
12-19 \text { years }\end{array}$ \\
\hline Female & Child's gender & $\begin{array}{l}\text { Male }=0 \\
\text { Female }=1\end{array}$ \\
\hline Race/ethnicity & Child's race/ethnicity & $\begin{array}{l}\text { Non-Hispanic Black (ref.) } \\
\text { Non-Hispanic White } \\
\text { Hispanic } \\
\text { Other }\end{array}$ \\
\hline BMI category & $\begin{array}{l}\text { Child's BMl calculated from parent-measured height and weight } \\
\text { using the formula [weight }(\mathrm{kg})] /[\text { height }(\mathrm{m})]^{2} \\
\text { Age- and gender-specific BMI percentiles calculated based on } \\
\text { CDC growth charts }\end{array}$ & $\begin{array}{l}\text { Overweight and obese defined as } \\
\text { those } \geq 85 \text { th percentile and } \\
\text { coded }=1, \text { else }=0\end{array}$ \\
\hline \multicolumn{3}{|l|}{ Parent demographics } \\
\hline Mother's education & $\begin{array}{l}\text { Highest level of education completed by mother (if mother did not } \\
\text { live in the house, respondent's education was used) }\end{array}$ & $\begin{array}{l}\text { High school or less (ref.) } \\
\text { Some college } \\
\text { College plus }\end{array}$ \\
\hline Nativity & Whether parent US born or foreign born & $\begin{array}{l}\text { Parent US born }=0 \\
\text { Parent foreign born }=1\end{array}$ \\
\hline Parent BMI & $\begin{array}{l}\text { Parent-measured height and weight converted into BMI using the } \\
\text { formula [weight }(\mathrm{kg})] /[\text { height }(\mathrm{m})]^{2}\end{array}$ & \\
\hline \multicolumn{3}{|l|}{ Household characteristics } \\
\hline Poverty status & Household income as ratio of the federal poverty level & $\begin{array}{l}\leq 200 \%=0 \\
>200 \%=1\end{array}$ \\
\hline SNAP participation & Household's participation SNAP & $\begin{array}{l}\mathrm{Yes}=1 \\
\mathrm{No}=0\end{array}$ \\
\hline $\begin{array}{l}\text { Other federal programme } \\
\text { participation }\end{array}$ & Household's participation in TANF and SSI & $\begin{array}{l}\mathrm{Yes}=1 \\
\mathrm{No}=0\end{array}$ \\
\hline Food secure & Did the household have enough food to eat? ${ }^{(57)}$ & $\begin{array}{l}\text { Yes }=1 \\
\mathrm{No}=0\end{array}$ \\
\hline $\begin{array}{l}\text { Non-English speaking } \\
\text { household }\end{array}$ & Language spoken at home & $\begin{array}{l}\text { Non-English }=1 \\
\text { English }=0\end{array}$ \\
\hline Car for food shopping & Did the household have a car available for food shopping? & $\begin{array}{l}\text { Yes }=1 \\
\text { No }=0\end{array}$ \\
\hline \multicolumn{3}{|l|}{ Neighbourhood characteristics } \\
\hline Neighbourhood income & $\begin{array}{l}\text { Median census block group income for census block group of } \\
\text { residence }^{(31)} \text { categorized into tertiles }\end{array}$ & $\begin{array}{l}\text { Lower }=\text { bottom tertile }(\text { ref. }) \\
\text { Middle }=\text { middle tertile } \\
\text { Higher }=\text { upper tertile }\end{array}$ \\
\hline Neighbourhood race & $\begin{array}{l}\text { Proportion of population in block group of residence that was } \\
\text { White, Black, Hispanic, other }{ }^{(31)} \text {. Categorized as majority race } \\
\text { of block group if proportion of population of specific race }>50 \%\end{array}$ & $\begin{array}{l}\text { Majority Black: }>50 \% \text { Black (ref.) } \\
\text { Majority White: }>50 \% \text { White } \\
\text { Majority Hispanic: }>50 \% \text { Hispanic } \\
\text { Mixed: no racial majority }\end{array}$ \\
\hline \multicolumn{2}{|c|}{ Parental perceptions of neighbourhood } & Dichotomized for analvsis \\
\hline neighbourhood $^{(51)}$ & $\begin{array}{l}\text { Responses on a 4-point Likert scale from 'strongly agree' to } \\
\text { 'strongly disagree' }\end{array}$ & $\begin{array}{l}\text { Disagree }=0 \\
\text { Agree }=1\end{array}$ \\
\hline $\begin{array}{l}\text { Safety from crime/safety } \\
\text { from traffic in } \\
\text { neighbourhood }^{(52-54)}\end{array}$ & $\begin{array}{l}\text { 'Thinking about traffic/crime, how safe is it to walk, run, bike, or } \\
\text { play in your neighbourhood?' Responses on a 4-point } \\
\text { Likert scale from 'very unsafe' to 'very safe' }\end{array}$ & $\begin{array}{l}\text { Dichotomized for analysis } \\
\text { Unsafe }=0 \\
\text { Safe }=1\end{array}$ \\
\hline $\begin{array}{l}\text { Neighbourhood pleasant } \\
\text { for } \mathrm{PA}^{(52-54)}\end{array}$ & $\begin{array}{l}\text { 'How pleasant is it to walk, run, bike or play in your } \\
\text { neighbourhood?' Responses on a 4-point Likert scale from } \\
\text { 'very unpleasant' to 'very pleasant' }\end{array}$ & $\begin{array}{l}\text { Dichotomized for analysis } \\
\text { Unpleasant }=0 \\
\text { Pleasant }=1\end{array}$ \\
\hline $\begin{array}{l}\text { Parks to play in } \\
\text { neighbourhood }^{(54)}\end{array}$ & $\begin{array}{l}\text { 'Are there parks in your neighbourhood where children can walk, } \\
\text { run, bike or play?' }\end{array}$ & $\begin{array}{l}\text { No }=0 \\
\text { Yes }=1\end{array}$ \\
\hline $\begin{array}{l}\text { PA facilities in } \\
\text { neighbourhood }^{(54)}\end{array}$ & $\begin{array}{l}\text { 'Are there indoor or outdoor exercise facilities in your } \\
\text { neighbourhood?' }\end{array}$ & $\begin{array}{l}\text { No }=0 \\
\text { Yes }=1\end{array}$ \\
\hline Sidewalk condition ${ }^{(54)}$ & 'Are the sidewalks generally in good, fair or poor condition?' & $\begin{array}{l}\text { Dichotomized for analysis } \\
\text { Poor }=0 \\
\text { Good }=1\end{array}$ \\
\hline Ease of getting to store $e^{(55)}$ & $\begin{array}{l}\text { 'How easy is it for you/your family to get to your main food store?' } \\
\text { Response on a 4-point Likert scale from 'very easy' to 'very } \\
\text { difficult' }\end{array}$ & $\begin{array}{l}\text { Dichotomized for analysis } \\
\text { Difficult }=0 \\
\text { Easy }=1\end{array}$ \\
\hline FV available ${ }^{(54,56)}$ & $\begin{array}{l}\text { A composite variable of availability and selection of good FV at } \\
\text { main store } \\
\text { Availability: 'How available are fresh fruits and vegetables at your } \\
\text { main food shopping store?' } \\
\text { Selection: 'Is there a large selection of good-quality fresh fruits } \\
\text { and vegetables at your main food shopping store?' } \\
\text { Responses on a 4-point Likert scale from 'very limited selection' } \\
\text { to 'very large selection' }\end{array}$ & Cronbach's $a=0.556$ \\
\hline
\end{tabular}


Table 1 Continued

\begin{tabular}{|c|c|c|}
\hline Variable name & Definition and description & Variable codes and categories \\
\hline FV inexpensive ${ }^{(54)}$ & $\begin{array}{l}\text { 'How expensive are fresh fruits and vegetables at your main food } \\
\text { shopping store?' Responses on a 4-point Likert scale from } \\
\text { 'very expensive' to 'very inexpensive' }\end{array}$ & $\begin{array}{l}\text { Dichotomized for analysis } \\
\text { Expensive }=0 \\
\text { Inexpensive }=1\end{array}$ \\
\hline LFF available ${ }^{(56)}$ & $\begin{array}{l}\text { A composite variable of availability and selection of low-fat foods } \\
\text { at main store } \\
\text { Availability: 'How available are low-fat foods at your main food } \\
\text { shopping store?' } \\
\text { Selection: 'Is there a large selection of good-quality low-fat foods } \\
\text { at your main food shopping store?' } \\
\text { Responses on a 4-point Likert scale from 'very limited selection' } \\
\text { to 'very large selection' }\end{array}$ & Cronbach's $a=0.631$ \\
\hline LFF inexpensive ${ }^{(54)}$ & $\begin{array}{l}\text { 'How expensive are low-fat foods at your main food shopping } \\
\text { store?' Responses on a 4-point Likert scale from 'very } \\
\text { expensive' to 'very inexpensive' }\end{array}$ & $\begin{array}{l}\text { Dichotomized for analysis } \\
\text { Expensive }=0 \\
\text { Inexpensive }=1\end{array}$ \\
\hline Buy FV at main food store & $\begin{array}{l}\text { 'In the past month, did you usually buy most of your fruits and } \\
\text { vegetables at the same store where you do most of your } \\
\text { shopping?' Responses were 'at the same store' or } \\
\text { 'somewhere else' }\end{array}$ & $\begin{array}{l}\text { Somewhere else }=0 \\
\text { At the same store }=1\end{array}$ \\
\hline \multicolumn{3}{|c|}{ Geospatial variables (GIS measures) } \\
\hline $\begin{array}{l}\text { Presence of large park in } \\
0.40 \mathrm{~km}(1 / 4 \mathrm{mile})\end{array}$ & $\begin{array}{l}\text { Presence of a large park greater than } 0.40 \text { ha }(1 \text { acre }) \text { in size } \\
\text { within } 0.40 \mathrm{~km}(1 / 4 \text { mile }) \text { of a child's residence based on roadway } \\
\text { network }\end{array}$ & $\begin{array}{l}\text { Absent }=0 \\
\text { Present }=1\end{array}$ \\
\hline $\begin{array}{l}\text { Presence of PA facility in } \\
0.40 \mathrm{~km}(1 / 4 \text { mile })\end{array}$ & $\begin{array}{l}\text { Presence of a public or private indoor or outdoor PA facility within } \\
0.40 \mathrm{~km}(1 / 4 \text { mile) of a child's residence based on roadway } \\
\text { network }\end{array}$ & $\begin{array}{l}\text { Absent }=0 \\
\text { Present }=1\end{array}$ \\
\hline $\begin{array}{l}\text { Presence of supermarket in } \\
0.40 \mathrm{~km}(1 / 4 \mathrm{mile})\end{array}$ & $\begin{array}{l}\text { Presence of a large chain supermarket within } 0.40 \mathrm{~km}(1 / 4 \mathrm{mile}) \text { of } \\
\text { a child's residence based on roadway network }\end{array}$ & $\begin{array}{l}\text { Absent }=0 \\
\text { Present }=1\end{array}$ \\
\hline $\begin{array}{l}\text { Presence of convenience } \\
\text { store in } 0.40 \mathrm{~km}(1 / 4 \mathrm{mile})\end{array}$ & $\begin{array}{l}\text { Presence of a convenience store within } 0.40 \mathrm{~km}(1 / 4 \mathrm{mile}) \text { of a } \\
\text { child's residence based on roadway network }\end{array}$ & $\begin{array}{l}\text { Absent }=0 \\
\text { Present }=1\end{array}$ \\
\hline $\begin{array}{l}\text { Presence of limited-service } \\
\text { restaurant in } 0.40 \mathrm{~km} \\
(1 / 4 \text { mile })\end{array}$ & $\begin{array}{l}\text { Presence of a limited-service restaurant (where patrons pay } \\
\text { before eating) within } 0.40 \mathrm{~km}(1 / 4 \text { mile) of a child's residence } \\
\text { based on roadway network }\end{array}$ & $\begin{array}{l}\text { Absent }=0 \\
\text { Present }=1\end{array}$ \\
\hline $\begin{array}{l}\text { Presence of healthy food } \\
\text { outlet in } 0.40 \mathrm{~km}(1 / 4 \mathrm{mile})\end{array}$ & $\begin{array}{l}\text { Presence of a small store that sells at least five fruits, five } \\
\text { vegetables, low-fat milk, fresh meat within } 0.40 \mathrm{~km}(1 / 4 \mathrm{mile}) \text { of a } \\
\text { child's residence based on roadway network }\end{array}$ & $\begin{array}{l}\text { Absent }=0 \\
\text { Present }=1\end{array}$ \\
\hline
\end{tabular}

SNAP, Supplemental Nutrition Assistance Program; PA, physical activity; FV, fruit and vegetables; LFF, low-fat foods; GIS, geographical information system; CDC, Centers for Disease Control and Prevention; TANF, Temporary Assistance to Need Families; SSI, Supplemental Security Initiative; ref., referent category.

(1 acre) in size were included as they were most likely to offer opportunities for being physically active. These data sources were supplemented with commercial data purchased from InfoUSA for NAICS (North American Industry Classification System) codes associated with fitness and recreational sports centres and amusement and recreational facilities. Each PA facility included in the final database was investigated to ensure that it offered programmes for 3-18-year-olds. All food outlets and PA facilities were geocoded to create proximity measures. The roadway network distance from each respondent's home to the nearest facility was estimated using the distance tools in the geographical information system ArcGIS version 10·1.

\section{Study sample}

The sample used for the present study included 560 children whose parents completed and returned the worksheet with measured heights and weights (excluding any biologically implausible values ${ }^{(34)}$ ) and had complete data on the explanatory variables. Sampling weights were developed specifically for children with returned worksheets to ensure that the survey estimates represent the population of $3-18$-year-olds in the four cities combined. Because only $40.5 \%$ of the survey respondents who provided their mailing addresses returned completed worksheets, self-selection bias is a potential concern. However, recent work using similar statistical modelling examined the effects of such biases in detail and found that they were negligible ${ }^{(22)}$.

Survey fieldwork and initial geocoding were carried out by Abt SRBI Inc. This research was approved by the Institutional Review Boards of Rutgers University and Arizona State University. Participants provided informed consent prior to enrolling in the study.

\section{Measures}

Outcome variable

The dependent variable was a dichotomous indicator of child overweight or obese (OW/OB) status based on the age- and sex-specific percentile of the child's BMI calculated with the measured height and weight provided on the parents' worksheet and the 2000 growth charts of the Centers for Disease Control and Prevention ${ }^{(35)}$. Children with a BMI at or above the 85th percentile were classified as OW/OB. 


\section{Explanatory variables - layers of the Social Ecological Model}

Table 1 provides the sources and definitions and survey questions used for constructing each of the exposure variables, along with the coding scheme used, and the psychometric statistics for composite variables. Data for SEM layers were collected for the child, parent and household levels, for parental perception of the neighbourhood built environment and for neighbourhood income and race.

Access to healthy and unhealthy environments was measured by proximity of food and PA outlets to each individual child's residence. Based on prior work, presence or absence of food and PA outlets within $0.40 \mathrm{~km}$ $(1 / 4$ mile) of the respondent's home based on the roadway network was used to capture proximity to a food or PA outlet $^{(22)}$. These measures of proximity have also been found by other researchers ${ }^{(12,14,16,26,36,37)}$ to be significantly associated with children's weight status.

\section{Analysis}

Descriptive and bivariate statistics were examined for all variables in the analysis. Survey-weighted logistic regression analyses were performed using the svy: logistic procedure in the Stata statistical software package version 12.0 to predict the odds that a child was OW/OB. In these analyses differential sampling probabilities as well as clustering at the city and household levels were accounted for, thus yielding appropriately adjusted standard errors to be used in tests of significance. Elements from each of the six SEM layers (Fig. 1, Table 1) were included in the regression model as predictors based on previous research $^{(10,16,22,25,26,38-42)}$. Using the logistic regression estimates from this initial stage, we then determined whether the elements of each SEM layer were jointly significant in predicting child weight status with Wald tests for complex survey data ${ }^{(43)}$, generated by Stata's lincom procedure. Statistical tests were considered significant at $P<0.05$.

Additional analyses were conducted to assess the relative contribution of different layers of the SEM to the prediction of child's weight. Specifically, a recently developed and validated $R^{2}$ measure called the coefficient of discrimination ${ }^{(44)}$ (or Tjur $R^{2}$ ), which can be easily applied to logistic regression with complex survey data, was used. The Tjur $R^{2}$ measures the difference between the mean predicted probability of being OW/OB among children known to be in that category and the mean predicted probability of being OW/OB among children not in that category ${ }^{(44)}$. The Tjur $R^{2}$ is conceptually similar to the more familiar $R^{2}$ statistic in an ordinary least squares (OLS) regression model where, like the OLS $R^{2}$, the Tjur $R^{2}$ is equal to 1 if the model perfectly predicts the outcome for each observation, equals 0 if the model has no explanatory or discriminatory power at all, and lies between 0 and 1 for intermediate cases. However, while the OLS $R^{2}$ measures the percentage of variation in the (usually continuous) dependent variable that is explained by the independent variables in the model, the Tjur $R^{2}$, specific to a binary dependent variable, measures the extent to which the independent variables in the model can discriminate between observations holding the two values for a dichotomous dependent variable. Intuitively, if a layer of the SEM was a very strong predictor of child weight status, then the removal of that layer from the full model would cause a large reduction in the Tjur $R^{2}$. Conversely, the removal of a weakly predictive layer would cause a negligible reduction in the Tjur $R^{2}$. Thus, the differences suggest the relative contribution of each SEM layer to the prediction of child weight status.

\section{Results}

Forty per cent of the children were OW/OB; $50.4 \%$ of the children were non-Hispanic Black and 39.4\% were Hispanic (Table 2). Rates of OW/OB were highest among 6-11-year-olds (50.6\%) compared with 3-5-year-olds (28.4\%) and 12-19 year-olds (36.0\%). Parents of OW/OB children had significantly higher BMI than other parents $\left(31.7 v .28 .4 \mathrm{~kg} / \mathrm{m}^{2}\right)$. Lowest levels of OW/OB prevalence were observed among children living in mixed neighbourhoods $(27.9 \%)$ and those living in higher-income neighbourhoods (31.0\%). Forty-four per cent of children living within $0.40 \mathrm{~km}(1 / 4 \mathrm{mile})$ of a convenience store were OW/OB compared with $25.6 \%$ of those who did not.

Table 3 shows the results from a logistic regression analysis indicating the odds of a child being OW/OB for each predictor variable after adjusting for the effect of all other variables in the model. Table 3 also includes the results of a test of joint significance for each layer of the SEM, which shows the collective predictive power of the variables included in a particular layer after adjusting for the effect of all other layers in the model. For five of the six layers included in the analysis (geospatial measures of neighbourhood, parental perception of neighbourhood, neighbourhood characteristics, parent demographics and child demographics), the test of joint significance for the layer was statistically significant $(P<0.05)$ indicating that elements in each of these layers were collectively significant predictors of a child's obesity status after adjusting for all other variables in the model. The test of joint significance for the sixth layer representing household characteristics approached significance at $P=0.088$. Within the six layers examined, objectively measured proximity to parks $(P<0.01)$, parents' report of ease of getting to their main food store $(P<0.05)$, parents' reported ability to purchase fruits and vegetables at their main food shopping stores $(P<0 \cdot 01)$, child's residence in majority White and mixed neighbourhoods $(P<0.05)$, higher neighbourhood income $(P<0.01)$ and higher level of mother's education $(P<0.05)$ were significantly inversely associated with a child's odds of being OW/OB, while 
Table 2 Description of demographic characteristics of children and parents, parental perceptions of food and PA environments and geospatial variables for all children and children categorized as OW/OB and not OW/OB; random sample of households living in low-income, racially diverse communities in four cities in the state of New Jersey, USA, 2009-2010 (New Jersey Childhood Obesity Study)

\begin{tabular}{|c|c|c|c|c|}
\hline & \multirow{2}{*}{$\begin{array}{c}\begin{array}{c}\text { All children } \\
\left(n 560^{*}\right)\end{array} \\
\%, \text { mean or SD }\end{array}$} & \multirow{2}{*}{$\begin{array}{c}\text { OW/OB } \\
\left(n 223^{*}\right)\end{array}$} & \multirow{2}{*}{$\begin{array}{c}\begin{array}{c}\text { Not OW/OB } \\
\left(n 337^{*}\right)\end{array} \\
\%, \text { mean or SD }\end{array}$} & \multirow{2}{*}{$\begin{array}{c}P \text { value for difference } \\
\text { between } \mathrm{OW} / \mathrm{OB} v \text {. } \\
\text { not } \mathrm{OW} / \mathrm{OB}\end{array}$} \\
\hline & & & & \\
\hline \multicolumn{5}{|l|}{ Child demographics } \\
\hline Age $(\%)$ & & & & 0.005 \\
\hline $3-5$ years & 17.4 & 28.4 & 71.6 & \\
\hline $6-11$ years & $40 \cdot 0$ & $50 \cdot 6$ & $49 \cdot 4$ & \\
\hline $12-19$ years & $42 \cdot 6$ & $36 \cdot 0$ & 64.0 & \\
\hline Gender (\%) & & & & 0.99 \\
\hline Female & $47 \cdot 7$ & $40 \cdot 5$ & 59.5 & \\
\hline Male & $52 \cdot 3$ & $40 \cdot 6$ & 59.4 & \\
\hline Race/ethnicity (\%) & & & & 0.80 \\
\hline Non-Hispanic White & 4.9 & 29.9 & $70 \cdot 1$ & \\
\hline Non-Hispanic Black & $50 \cdot 4$ & $42 \cdot 4$ & $57 \cdot 6$ & \\
\hline Hispanic & $39 \cdot 4$ & $39 \cdot 2$ & $60 \cdot 8$ & \\
\hline Other & 5.4 & $42 \cdot \overline{7}$ & $57 \cdot 3$ & \\
\hline \multicolumn{5}{|l|}{ BMI category (\%) } \\
\hline Not OW/OB & 59.5 & & & \\
\hline $\mathrm{OW} / \mathrm{OB}$ & 40.5 & & & \\
\hline \multicolumn{5}{|l|}{ Parent demographics } \\
\hline Mother's education (\%) & & & & $0 \cdot 16$ \\
\hline High school or less & $57 \cdot 1$ & $45 \cdot 3$ & 54.7 & \\
\hline Some college & 28.5 & 34.7 & $65 \cdot 3$ & \\
\hline College plus & 14.4 & $33 \cdot 3$ & $66 \cdot 7$ & \\
\hline Nativity (\%) & & & & 0.35 \\
\hline Foreign born & $31 \cdot 1$ & $36 \cdot 6$ & 63.4 & \\
\hline US born & 68.9 & $42 \cdot 3$ & $57 \cdot 7$ & \\
\hline Parent BMI $\left(\mathrm{kg} / \mathrm{m}^{2}\right)$ & & & & $<0.001$ \\
\hline Mean & $29 \cdot 7$ & $31 \cdot 7$ & $28 \cdot 4$ & \\
\hline SD & 6.59 & $6 \cdot 80$ & 6.07 & \\
\hline \multicolumn{5}{|l|}{ Household characteristics } \\
\hline Household poverty status (\%) & & & & 0.29 \\
\hline$\leq 200 \% \mathrm{FPL}$ & $81 \cdot 1$ & $42 \cdot 0$ & 58.0 & \\
\hline$>200 \% \mathrm{FPL}$ & $18 \cdot 9$ & 34.0 & $66 \cdot 0$ & \\
\hline SNAP participation (\%) & & & & 0.08 \\
\hline Yes & $28 \cdot 3$ & $48 \cdot 1$ & 51.9 & \\
\hline No & 71.7 & $37 \cdot 6$ & 62.4 & \\
\hline Other federal programme participation (\%) & & & & 0.78 \\
\hline Yes & $27 \cdot 9$ & $41 \cdot 8$ & $58 \cdot 2$ & \\
\hline No & $72 \cdot 1$ & $40 \cdot 0$ & $60 \cdot 0$ & \\
\hline Food secure (\%) & & & & 0.39 \\
\hline Yes & $80 \cdot 2$ & 41.6 & 58.4 & \\
\hline No & $19 \cdot \overline{8}$ & $36 \cdot 0$ & 64.0 & \\
\hline Non-English speaking household (\%) & & & & 0.53 \\
\hline Yes & $25 \cdot 4$ & 38.4 & 61.6 & \\
\hline No & 74.6 & 41.2 & $58 \cdot 8$ & \\
\hline Car for food shopping (\%) & & & & 0.13 \\
\hline Yes & 91.8 & 39.4 & $60 \cdot 6$ & \\
\hline No & 8.2 & $53 \cdot 3$ & $46 \cdot 7$ & \\
\hline \multicolumn{5}{|l|}{ Neighbourhood characteristics } \\
\hline Neighbourhood income (\%) & & & & 0.06 \\
\hline Lower & $32 \cdot 3$ & $46 \cdot 1$ & 53.9 & \\
\hline Middle & 33.9 & 44.6 & 55.4 & \\
\hline Higher & 33.8 & 31.0 & $69 \cdot 0$ & \\
\hline Neighbourhood race (\%) & & & & 0.24 \\
\hline Majority Black & $52 \cdot 6$ & $42 \cdot 3$ & $57 \cdot 7$ & \\
\hline Majority White & 5.4 & $50 \cdot 3$ & 49.7 & \\
\hline Majority Hispanic & 29.5 & $40 \cdot 8$ & $59 \cdot 2$ & \\
\hline Mixed & 12.5 & 27.9 & $72 \cdot 1$ & \\
\hline \multicolumn{5}{|l|}{ Parental perceptions of neighbourhood } \\
\hline PA opportunities in neighbourhood (\%) & & & & 0.97 \\
\hline Agree & 43.9 & 40.4 & 59.6 & \\
\hline Disagree & $56 \cdot 1$ & $40 \cdot 6$ & 59.4 & \\
\hline Safety from traffic in neighbourhood (\%) & & & & 0.32 \\
\hline Unsafe & $14 \cdot 2$ & 34.0 & $66 \cdot 0$ & \\
\hline Safe & $85 \cdot 8$ & 41.6 & 58.4 & \\
\hline Safety from crime in neighbourhood (\%) & & & & 0.20 \\
\hline Unsafe & $22 \cdot 2$ & 33.6 & $66 \cdot 4$ & \\
\hline Safe & $77 \cdot 8$ & 42.5 & 57.5 & \\
\hline
\end{tabular}




\begin{tabular}{|c|c|c|c|c|}
\hline & $\begin{array}{l}\text { All children } \\
\left(n 560^{*}\right)\end{array}$ & $\begin{array}{l}\mathrm{OW} / \mathrm{OB} \\
\left(n 223^{*}\right)\end{array}$ & $\begin{array}{l}\text { Not OW/OB } \\
\left(n 337^{*}\right)\end{array}$ & \multirow{2}{*}{$\begin{array}{c}P \text { value for difference } \\
\text { between } \mathrm{OW} / \mathrm{OB} v \text {. } \\
\text { not } \mathrm{OW} / \mathrm{OB}\end{array}$} \\
\hline & $\%$, mean or SD & $\%$, mean or SD & $\%$, mean or SD & \\
\hline Neighbourhood pleasant for PA (\%) & & & & $0 \cdot 70$ \\
\hline Unpleasant & $15 \cdot 0$ & $43 \cdot 2$ & $56 \cdot 8$ & \\
\hline Pleasant & $85 \cdot 0$ & $40 \cdot 0$ & $60 \cdot 0$ & \\
\hline Parks to play in neighbourhood (\%) & & & & 0.93 \\
\hline Yes & $79 \cdot 3$ & $40 \cdot 7$ & $59 \cdot 3$ & \\
\hline No & $20 \cdot 7$ & $40 \cdot 0$ & $60 \cdot 0$ & \\
\hline PA facilities in neighbourhood (\%) & & & & 0.06 \\
\hline Yes & $61 \cdot 6$ & $55 \cdot 0$ & $65 \cdot 9$ & \\
\hline No & $38 \cdot 4$ & $45 \cdot 0$ & $34 \cdot 1$ & \\
\hline Sidewalk condition (\%) & & & & $0 \cdot 70$ \\
\hline Good & 93.4 & $40 \cdot 3$ & $59 \cdot 7$ & \\
\hline Poor & $6 \cdot 6$ & $43 \cdot 8$ & $56 \cdot 2$ & \\
\hline Ease of getting to store (\%) & & & & $0 \cdot 16$ \\
\hline Easy & $68 \cdot 0$ & $38 \cdot 0$ & $62 \cdot 0$ & \\
\hline Difficult & $32 \cdot 0$ & $46 \cdot 0$ & $54 \cdot 0$ & \\
\hline FV available & & & & 0.75 \\
\hline Mean no. & 7.43 & $7 \cdot 41$ & 7.44 & \\
\hline SD & 0.99 & 0.95 & 1.01 & \\
\hline FV inexpensive (\%) & & & & 0.79 \\
\hline Agree & 38.4 & 41.5 & $58 \cdot 5$ & \\
\hline Disagree & $61 \cdot 6$ & 39.9 & $60 \cdot 1$ & \\
\hline LFF available & & & & 0.68 \\
\hline Mean no. & $7 \cdot 10$ & $7 \cdot 07$ & $7 \cdot 12$ & \\
\hline SD & $1 \cdot 13$ & $1 \cdot 16$ & $1 \cdot 11$ & \\
\hline LFF inexpensive (\%) & & & & 0.44 \\
\hline Agree & 29.5 & $43 \cdot 8$ & $56 \cdot 2$ & \\
\hline Disagree & $70 \cdot 5$ & $39 \cdot 1$ & $60 \cdot 9$ & \\
\hline Buy FV at main food store (\%) & & & & 0.12 \\
\hline At the main store & 73.4 & $38 \cdot 0$ & $62 \cdot 0$ & \\
\hline Somewhere else & $26 \cdot 6$ & 47.5 & 52.5 & \\
\hline Geospatial variables (GIS measures) & & & & \\
\hline Presence of large park in $0.40 \mathrm{~km}(1 / 4 \mathrm{mile})(\%)$ & & & & $0 \cdot 19$ \\
\hline Present & $49 \cdot 7$ & $36 \cdot 8$ & $63 \cdot 2$ & \\
\hline Absent & $50 \cdot 3$ & $44 \cdot 2$ & $55 \cdot 8$ & \\
\hline Presence of PA facility in $0.40 \mathrm{~km}$ ( $1 / 4$ mile) $(\%)$ & & & & $0 \cdot 83$ \\
\hline Present & $11 \cdot 8$ & $39 \cdot 1$ & $60 \cdot 9$ & \\
\hline Absent & $88 \cdot 2$ & $40 \cdot 7$ & $59 \cdot 3$ & \\
\hline Presence of supermarket in $0.40 \mathrm{~km}(1 / 4$ mile $)(\%)$ & & & & $0 \cdot 16$ \\
\hline Present & $9 \cdot 0$ & $26 \cdot 8$ & 73.2 & \\
\hline Absent & $91 \cdot 0$ & 41.9 & $58 \cdot 1$ & \\
\hline Presence of convenience store in $0.40 \mathrm{~km}(1 / 4 \mathrm{mile})(\%)$ & & & & 0.005 \\
\hline Present & $81 \cdot 2$ & $44 \cdot 0$ & $56 \cdot 0$ & \\
\hline Absent & $18 \cdot 8$ & $25 \cdot 6$ & $74 \cdot 4$ & \\
\hline $\begin{array}{l}\text { Presence of limited-service restaurant in } 0.40 \mathrm{~km} \\
(1 / 4 \mathrm{mile})(\%)\end{array}$ & & & & 0.46 \\
\hline Present & $68 \cdot 1$ & $39 \cdot 0$ & $61 \cdot 0$ & \\
\hline Absent & 31.9 & 43.7 & $56 \cdot 3$ & \\
\hline Presence of healthy food outlet in $0.40 \mathrm{~km}(1 / 4 \mathrm{mile})(\%)$ & & & & 0.41 \\
\hline Present & $25 \cdot 6$ & 44.4 & $55 \cdot 6$ & \\
\hline Absent & $74 \cdot 4$ & $39 \cdot 2$ & $60 \cdot 8$ & \\
\hline
\end{tabular}

OW/OB, overweight/obese; FPL, federal poverty level; SNAP, Supplemental Nutrition Assistance Program; PA, physical activity; FV, fruit and vegetables; LFF, low-fat foods; GIS, geographical information system.

Analysis based on weighed sample and adjusted for complex survey design.

*Unweighted $n$.

parent BMI $(P<0 \cdot 01)$ and child's age $(P<0 \cdot 01)$ were positively associated. Other individual variable associations with child's OW/OB status that approached significance were an inverse association with household participation in SNAP (Supplemental Nutrition Assistance Program; $P=0 \cdot 06)$ and positive associations with parents' perception of safety from crime in neighbourhood $(P=0.08)$ and non-English speaking household $(P=0 \cdot 09)$.
Table 3 also shows the Tjur $R^{2}$ for the full model and for models where elements from each layer were removed. In the full model, the Tjur $R^{2}$ was equal to 0.157 which means that, on average, the predicted probability of being OW/OB was 15.7 percentage points higher for children who truly were OW/OB relative to children who were not. When the layer representing geospatial measures of environment was removed from the full model 
Table 3 Logistic regression analysis of the associations between child weight status and layers of the Social Ecological Model; random sample of households living in low-income, racially diverse communities in four cities in the state of New Jersey, USA, $2009-2010$ (New Jersey Childhood Obesity Study)

\begin{tabular}{|c|c|c|c|c|c|}
\hline$n 560^{*}$ & Adjusted OR & $95 \% \mathrm{Cl}$ & $P$ value & Joint significance $†$ & Tjur $R^{2}$ \\
\hline Overall model & & & & & 0.157 \\
\hline \multicolumn{6}{|l|}{ Geospatial variables (GIS measures) } \\
\hline Presence of large park in $0.40 \mathrm{~km}(1 / 4$ mile $)$ & 0.41 & $0.24,0.70$ & 0.001 & $F(6,480)=2 \cdot 38$ & 0.140 \\
\hline Presence of PA facility in $0.40 \mathrm{~km}(1 / 4$ mile $)$ & 0.51 & $0.22,1.19$ & 0.12 & $P=0.028$ & \\
\hline Presence of supermarket in $0.40 \mathrm{~km}(1 / 4 \mathrm{mile})$ & 0.96 & $0.33,2.77$ & 0.94 & & \\
\hline Presence of convenience store in $0.40 \mathrm{~km}(1 / 4$ mile $)$ & 1.52 & $0.74,3.11$ & 0.26 & & \\
\hline Presence of limited-service restaurant in $0.40 \mathrm{~km} \mathrm{(1/4} \mathrm{mile)}$ & 0.67 & $0.38,1.20$ & 0.18 & & \\
\hline \multirow{2}{*}{\multicolumn{6}{|c|}{ Parental perceptions of neighbourhood }} \\
\hline & & & & & \\
\hline PA opportunities in neighbourhood & 0.90 & $0.54,1.51$ & 0.69 & $F(13,473)=1 \cdot 77$ & 0.109 \\
\hline Safety from traffic in neighbourhood & 1.31 & $0.55,3.07$ & 0.54 & $P=0.045$ & \\
\hline Safety from crime in neighbourhood & 1.90 & $0.92,3.95$ & 0.08 & & \\
\hline Neighbourhood pleasant for PA & 0.55 & $0.25,1.23$ & 0.15 & & \\
\hline Parks to play in neighbourhood & 1.58 & $0.82,3.05$ & 0.17 & & \\
\hline PA facilities in neighbourhood & 0.66 & $0.40,1 \cdot 10$ & 0.11 & & \\
\hline Good sidewalk condition & 0.70 & $0.29,1.68$ & 0.43 & & \\
\hline Easy to get to store & 0.56 & $0.32,0.98$ & 0.04 & & \\
\hline FV available & 0.99 & $0.78,1.25$ & 0.93 & & \\
\hline FV inexpensive & 0.86 & $0.49,1.52$ & 0.61 & & \\
\hline LFF available & 0.89 & $0.71,1.11$ & 0.29 & & \\
\hline LFF inexpensive & 1.38 & $0.80,2.38$ & 0.25 & & \\
\hline Buy FV at main food store & 0.39 & $0.22,0.68$ & 0.001 & & \\
\hline \multicolumn{6}{|l|}{ Neighbourhood characteristics } \\
\hline Neighbourhood income & & & & $F(5,481)=4 \cdot 10$ & 0.117 \\
\hline Lower (ref.) & & & & Prob $>F=0.001$ & \\
\hline Middle & 0.89 & $0.49,1.63$ & 0.72 & & \\
\hline Higher & 0.39 & $0.21,0.72$ & 0.003 & & \\
\hline \multicolumn{6}{|l|}{ Neighbourhood race } \\
\hline Majority Black (ref.) & & & & & \\
\hline Majority White & 7.32 & $1.95,27.5$ & 0.003 & & \\
\hline Majority Hispanic & 1.05 & $0.53,2.09$ & 0.88 & & \\
\hline Mixed & 0.45 & $0.21,0.94$ & 0.03 & & \\
\hline \multicolumn{6}{|l|}{ Household characteristics } \\
\hline Poverty status & & & & $F(6,480)=1.85$ & 0.144 \\
\hline$\leq 200 \%$ FPL (ref.) & & & & Prob $>F=0.088$ & \\
\hline$>200 \% \mathrm{FPL}$ & 1.69 & $0.76,3.78$ & 0.20 & & \\
\hline SNAP participation & 0.56 & $0.31,1.02$ & 0.06 & & \\
\hline Other federal programme participation & 1.60 & $0.89,2.90$ & 0.12 & & \\
\hline Food secure & 0.58 & $0.29,1.13$ & 0.11 & & \\
\hline Non-English speaking household & 1.99 & $0.89,4.41$ & 0.09 & & \\
\hline Car for food shopping & 0.59 & $0.26,1.33$ & 0.20 & & \\
\hline \multicolumn{6}{|l|}{ Parent demographics } \\
\hline Mother's education & & & & $F(4,482)=5.55$ & 0.103 \\
\hline High school or less (ref.) & & & & Prob $>F=.0002$ & \\
\hline Some college & 0.59 & $0.32,1.07$ & 0.08 & & \\
\hline College plus & 0.36 & $0.14,0.89$ & 0.03 & & \\
\hline Parent foreign born & 0.54 & $0.26,1.11$ & 0.10 & & \\
\hline Parent BMI & 1.09 & $1.04,1.14$ & $<0.001$ & & \\
\hline \multicolumn{6}{|l|}{ Child demographics } \\
\hline Age & & & & $F(6,480)=3.22$ & 0.138 \\
\hline $3-5$ years (ref.) & & & & Prob $>F=0.004$ & \\
\hline $6-11$ years & 3.07 & $1.58,5.95$ & 0.001 & & \\
\hline $12-19$ years & 1.28 & $0.65,2.49$ & 0.47 & & \\
\hline Female & 0.87 & $0.55,1.39$ & 0.57 & & \\
\hline \multicolumn{6}{|l|}{ Race/ethnicity } \\
\hline Non-Hispanic Black (ref.) & & & & & \\
\hline Non-Hispanic White & 0.57 & $0.20,1.67$ & 0.31 & & \\
\hline Hispanic & 0.84 & $0.41,1.73$ & 0.64 & & \\
\hline Other & 1.70 & $0.61,4.71$ & 0.31 & & \\
\hline
\end{tabular}

GIS, geographical information system; PA, physical activity; FV, fruit and vegetables; LFF, low-fat foods; ref., referent category; FPL, federal poverty level; SNAP, Supplemental Nutrition Assistance Program.

Analysis based on weighted sample and adjusted for complex survey design.

*Unweighted $n$.

†Joint significance calculated using testparm command in Stata software.

(without removing any other layers), the Tjur $R^{2}$ fell by 0.017 (from 0.157 to $0 \cdot 140$ ), which is a statistically significant reduction according to the Wald $F$ statistic
( $F=2 \cdot 38, P=0.028)$. The largest reduction in Tjur $R^{2}$ (0.054) was observed when elements from the layer consisting of parent-level characteristics were removed from 
the model, followed by the layers representing parental perceptions of the neighbourhood environment, neighbourhood characteristics, child demographics, geospatial neighbourhood measures and household characteristics.

\section{Discussion}

The role of different layers of the SEM in predicting children's OW/OB status among randomly selected, predominantly minority and low-income 3-18-year-old children living in low-income, racially diverse communities was examined. Five of the six layers of the SEM considered were significantly associated with children's OW/OB status. Based on the magnitude of reduction in Tjur $R^{2}$, the SEM layer representing parent characteristics made the largest contribution to children's weight status, followed by the layers representing parental perception of the neighbourhood food and PA environments, neighbourhood demographic characteristics, child characteristics, objectively measured presence of neighbourhood food and PA outlets, and finally household characteristics (which approached significance). It is important to note that the contribution for each layer depended heavily on the individual elements of that layer that were available for the current analysis. Although subsequent studies using different data elements could produce different findings, the current analysis was based on a rich source of data so that a comprehensive set of elements within each layer could be included. Moreover, the analysis used a fairly new and innovative analytic strategy, well-suited to assessing the empirical relevance of the SEM that can be applied to alternative databases to confirm and extend these findings.

Previous studies assessing correlates of different levels of the SEM have used analytic approaches that allow for estimating incremental contributions from each layer of the $\mathrm{SEM}^{(9,27)}$. Components of one level are entered first, and then incrementally components of the other layers are added, and the change in explanatory power of the model with each addition is assessed. A disadvantage of this approach is that findings for the first-entered layers may be biased because they are not independent of the effects of variables added in the succeeding layers. The approach used in the present study avoids these problems by assessing the marginal contribution of each layer of the SEM over and above all the other layers that appear in the full logistic regression model. As such, the independent contribution of each layer of the SEM on children's weight outcomes is estimated.

The present findings suggest that the layers of the SEM representing parent characteristics and parent perceptions of neighbourhoods are strong predictors of children's weight status. Previous studies have also found individual parent-level factors such as parental $\mathrm{BMI}^{(10,38,45)}$ and parent education ${ }^{(10,46)}$ to be independent predictors of children's weight status. Others have found strong evidence for associations of perceptions of the food and
PA environments with both food and PA behaviours, as well as with weight status in children ${ }^{(39,42)}$. The present study finds that while the layer representing parental perceptions of the food and PA environments and the one consisting of objectively measured geographical presence of food and PA outlets in the neighbourhood were both significantly associated with weight status, parental perceptions had a somewhat stronger association as determined by the magnitude of change in Tjur $R^{2}$. These findings suggest that parents are crucial targets for designing interventions aimed at preventing childhood obesity. It is likely that objective assessments based on geospatial measures capture proximity to different types of facilities, but do not assess their quality and extent of use. Parental perceptions, on the other hand, are based on more nuanced factors that may depend upon how these facilities look, feel and function from a parent's perspective. For example, in the analysis of various elements of parent perceptions of the neighbourhood environments, ease of getting to the store and parents' ability to purchase fruits and vegetables at the main food shopping store were independently associated with better weight outcomes among children. This suggests that even in communities where objectively assessed physical proximity to supermarkets is high, perception of accessibility and ability to find fruits and vegetables that meet the family's needs at the main food shopping store are important for the health of the children.

Studies examining inner-city low-income populations, similar to those investigated in the present study, show that living in close proximity to food outlets that offer unhealthy options, such as convenience stores, is associated with higher weight status ${ }^{(16,22,26)}$. In bivariate analysis, the presence of a convenience store was significantly associated with children being OW/OB, but after adjusting for the effect of covariates, specifically parental perceptions, the association was no longer significant, again suggesting the stronger influence of parental perception. In the present analysis, objectively measured presence of a park near a child's home (i.e. within $0.40 \mathrm{~km}$ or $1 / 4$ mile) was associated with lower odds of the child being OW/OB after adjusting for the effect of important covariates. Similar results have been reported by Potwarka et al. ${ }^{(25)}$. Consistent with other studies conducted in low-income areas ${ }^{(39,47)}$, weight status was not associated with perceptions of neighbourhood crime or traffic.

The layer of the SEM consisting of neighbourhood characteristics was also a significant contributor to children's weight status. Specifically, racial composition of the neighbourhood and neighbourhood income levels were significant predictors. Neighbourhood socio-economic status can influence types of assets and facilities that are available to residents ${ }^{(18,40,41,48,49)}$ and these may contribute to factors that predict children's health outcomes.

The present analyses confirm previous findings in showing that parent-level factors such as parent's BMI and 
education child-level factors such as age ${ }^{(46)}$ were significant predictors of weight outcomes. In this predominantly nonWhite and low-income sample, child's race and household income were not associated with weight outcomes. However, a marginal association was observed between SNAP participation and children's weight outcomes after adjusting for household poverty status and other variables in the model. Given the lack of consensus in the field and the current debate about the role of SNAP in curtailing the obesity epidemic, these finding are important in that they suggest in low-income minority communities, after adjusting for elements in different layers of the SEM, that SNAP participation may be protective against childhood obesity.

\section{Strengths and limitations}

The richness of the data reported here allows consideration of several layers of the SEM and assessment of their associations with children's weight outcomes after adjusting for important covariates. A wide age range of low-income children from non-Hispanic Black and Hispanic racial/ethnic groups was included, allowing for inferences about diverse subgroups of children living in low-income urban neighbourhoods.

The cross-sectional nature of the study design limits causal inferences. The response rate for the household survey ( $49 \%$ ) is similar to the response rate $(50 \cdot 2 \%)$ for the New Jersey Behavior Risk Factor Surveillance Survey (BRFSS) for $2010^{(50)}$. It is important to note that unlike our study, the BRFSS sample is not limited to lower-income populations among whom survey response rates tend to be lower. In addition, data on some layers of the SEM, in particular the school environment, were not available. School environments can play a critical role in shaping children's food and PA behaviours and their weight outcomes, especially among older children for whom school environments may play a larger role. Also, we evaluated the relative contribution of each layer of the SEM by examining changes in the Tjur $R^{2}$ when layers were removed from the full model. While this analysis provides an indication of the relative magnitude of the contributions, tests are not available to determine whether the changes in Tjur $R^{2}$ are statistically significant.

Overall, the findings from this application of the SEM suggest that, although parent characteristics, parent perceptions and neighbourhood demographic characteristics are most strongly associated with child's weight status, elements of the food and PA environment also offer leverage points for designing effective interventions.

\section{Conclusion}

The current analysis shows that the SEM is a viable framework to investigate factors at multiple levels that are independently associated with children's weight outcomes.
Elements representing six key layers of the SEM were examined and five of the six layers were found to contribute significantly to predicting children's weight status, with parent characteristics and parental perceptions of neighbourhood food and PA environments having the strongest association. Objectively measured geographical presence of food and PA outlets in neighbourhoods was also significantly associated with children's weight outcomes. Successful childhood obesity prevention strategies should focus on improving the built environment, as well as on engaging parents in promoting the use of such enhancements. The current analysis also introduces analytic strategies that can be used to generate additional knowledge about factors at multiple levels affecting childhood weight status, which can be critical for designing effective interventions.

\section{Acknowledgements}

Financial support: This research was funded by a grant (Grant \#64253) from the Robert Wood Johnson Foundation (RWJF). The RWJF had no role in the design, analysis or writing of this article. Conflict of interest: None. Authorship: P.O.-V. led the data analysis and writing of the manuscript. D.D. provided critical input in data analysis and writing of the manuscript. R.S.D. helped with data analysis and preparation of the manuscript. N.C.C. helped with conceptualizing the analysis plan. M.T. provided statistical support for data analysis. M.Y.J. led the design of the study and contributed to interpretation of findings and manuscript development. Ethics of buman subject participation: This research was approved by the Institutional Review Boards of Rutgers University and Arizona State University.

\section{References}

1. Koplan JP, Liverman CT \& Kraak VI (2005) Preventing Childhood Obesity: Health in the Balance, 1st ed. Washington, DC: The National Academies Press.

2. Davison KK \& Birch LL (2001) Childhood overweight: a contextual model and recommendations for future research. Obes Rev 2, 159-171.

3. Lobstein T, Baur L, Uauy R; IASO International Obesity TaskForce (2004) Obesity in children and young people: a crisis in public health. Obes Rev 5, Suppl. 1, 4-85.

4. Lytle LA (2009) Examining the etiology of childhood obesity: the IDEA study. Am J Community Psychol 44, 338-349.

5. Elder JP, Lytle L, Sallis JF et al. (2007) A description of the social-ecological framework used in the trial of activity for adolescent girls (TAAG). Health Educ Res 22, 156-165.

6. Centers for Disease Control and Prevention (2009) The Social-Ecological Model: A Framework for Prevention. http://www.cdc.gov/violenceprevention/overview/socialecologicalmodel.html (accessed July 2013).

7. Ogden CL, Carroll MD, Kit BK et al. (2012) Prevalence of obesity and trends in body mass index among US children and adolescents, 1999-2010. JAMA 307, 483-490.

8. Keane E, Layte R, Harrington J et al. (2012) Measured parental weight status and familial socioeconomic status 
correlates with childhood overweight and obesity at age 9 . PLOS ONE 7, e43503.

9. Elder JP, Arredondo EM, Campbell N et al. (2010) Individual, family, and community environmental correlates of obesity in Latino elementary school children. $J$ Sch Health 80, 20-30.

10. Chivers P, Parker H, Bulsara M et al. (2012) Parental and early childhood influences on adolescent obesity: a longitudinal study. Early Child Dev Care 182, 1071-1087.

11. Bhargava A, Jolliffe D \& Howard LL (2008) Socio-economic, behavioural and environmental factors predicted body weights and household food insecurity scores in the Early Childhood Longitudinal Study-Kindergarten. Br J Nutr 100, 438-444.

12. Epstein LH, Raja S, Daniel TO et al. (2012) The built environment moderates effects of family-based childhood obesity treatment over 2 years. Ann Behav Med 44, 248-258.

13. Saelens BE, Sallis JF, Frank LD et al. (2012) Obesogenic neighborhood environments, child and parent obesity: the Neighborhood Impact on Kids Study. Am J Prev Med 42, e57-e64.

14. Jilcott SB, Wade S, McGuirt JT et al. (2011) The association between the food environment and weight status among eastern North Carolina youth. Public Health Nutr 14, 1610-1617.

15. Mellor JM, Dolan CB \& Rapoport RB (2011) Child body mass index, obesity, and proximity to fast food restaurants. Int $J$ Pediatr Obes 6, 60-68.

16. Laska MN, Hearst MO, Forsyth A et al. (2010) Neighbourhood food environments: are they associated with adolescent dietary intake, food purchases and weight status? Public Health Nutr 13, 1757-1763.

17. Davis B \& Carpenter C (2009) Proximity of fast-food restaurants to schools and adolescent obesity. Am J Public Health 99, 505-510.

18. Fraser LK \& Edwards KL (2010) The association between the geography of fast food outlets and childhood obesity rates in Leeds, UK. Health Place 16, 1124-1128.

19. Crawford DA, Timperio AF, Salmon JA et al. (2008) Neighbourhood fast food outlets and obesity in children and adults: the CLAN study. Int J Pediatr Obes 3, 249-256.

20. Jeffery RW, Baxter J, McGuire M et al. (2006) Are fast food restaurants an environmental risk factor for obesity? Int $J$ Behav Nutr Phys Act 3, 2.

21. Burdette HL \& Whitaker RC (2004) Neighborhood playgrounds, fast food restaurants, and crime: relationships to overweight in low-income preschool children. Prev Med 38, 57-63.

22. Ohri-Vachaspati P, Lloyd K, DeLia D et al. (2013) A closer examination of the relationship between children's weight status and the food and physical activity environment. Prev Med 57, 162-167.

23. Oreskovic NM, Winickoff JP, Kuhlthau KS et al. (2009) Obesity and the built environment among Massachusetts children. Clin Pediatr 48, 904-912.

24. Bell JF, Wilson JS \& Liu GC (2008) Neighborhood greenness and 2-year changes in body mass index of children and youth. Am J Prev Med 35, 547-553.

25. Potwarka LR, Kaczynski AT \& Flack AL (2008) Places to play: association of park space and facilities with healthy weight status among children. J Community Health $\mathbf{3 3}$, 344-350.

26. Leung CW, Laraia BA, Kelly M et al. (2011) The influence of neighborhood food stores on change in young girls' body mass index. Am J Prev Med 41, 43-51.

27. Patnode CD, Lytle LA, Erickson DJ et al. (2010) The relative influence of demographic, individual, social, and environmental factors on physical activity among boys and girls. Int J Behav Nutr Phys Act 7, 79.
28. American Association for Public Opinion Research (2009) Response rates - an overview. http://www.aapor. org/Response_Rates_An_Overview.1.htm\#.U7xznlZBNG4 (accessed July 2013).

29. Carnell S \& Wardle J (2008) Appetite and adiposity in children: evidence for a behavioral susceptibility theory of obesity. Am J Clin Nutr 88, 22-29.

30. Huybrechts I, Himes JH, Ottevaere C et al. (2011) Validity of parent-reported weight and height of preschool children measured at home or estimated without home measurement: a validation study. BMC Pediatr 11, 63.

31. US Census Bureau (2013) American Community Survey Summary File. http://www.census.gov/acs/www/data_ documentation/summary_file/ (accessed July 2013).

32. Ohri-Vachaspati P, Martinez D, Yedidia MJ et al. (2011) Improving data accuracy of commercial food outlet databases. Am J Health Promot 26, 116-122.

33. Abercrombie LC, Sallis JF, Conway TL et al. (2008) Income and racial disparities in access to public parks and private recreation facilities. Am J Prev Med 34, 9-15.

34. Centers for Disease Control and Prevention (2000) Cut-offs to define outliers in the 2000 CDC Growth Charts. http:// www.cdc.gov/nccdphp/dnpa/growthcharts/resources/BIVcutoffs.pdf (accessed July 2013).

35. Centers for Disease Control and Prevention, National Center for Health Statistics (2009) CDC growth charts: United States. http://www.cdc.gov/growthcharts/cdc_charts.htm (accessed July 2013).

36. Jennings A, Welch A, Jones AP et al. (2011) Local food outlets, weight status, and dietary intake: associations in children aged 9-10 years. Am J Prev Med 40, 405-410.

37. Wolch J, Jerrett M, Reynolds K et al. (2011) Childhood obesity and proximity to urban parks and recreational resources: a longitudinal cohort study. Health Place 17, 207-214.

38. Li L, Law C, Lo Conte R et al. (2009) Intergenerational influences on childhood body mass index: the effect of parental body mass index trajectories. Am J Clin Nutr 89, 551-557.

39. Galvez MP, Pearl M \& Yen IH (2010) Childhood obesity and the built environment: a review of the literature from 20082009. Curr Opin Pediatr 22, 202-207.

40. Pearce J, Blakely T, Witten K et al. (2007) Neighborhood deprivation and access to fast-food retailing: a national study. Am J Prev Med 32, 375-382.

41. Powell LM, Slater S, Mirtcheva D et al. (2007) Food store availability and neighborhood characteristics in the United States. Prev Med 44, 189-195.

42. Bacha JM, Appugliese D, Coleman S et al. (2010) Maternal perception of neighborhood safety as a predictor of child weight status: the moderating effect of gender and assessment of potential mediators. Int J Pediatr Obes $\mathbf{5}$, 72-79.

43. Korn EL \& Graubard BI (1990) Simultaneous testing of regression coefficients with complex survey data: use of Bonferroni $t$ statistics. Am Stat 44, 270-276.

44. Tjur T (2009) Coefficients of determination in logistic regression models - a new proposal: the coefficient of discrimination. Am Stat 63, 366-372.

45. Strauss RS \& Knight J (1999) Influence of the home environment on the development of obesity in children. Pediatrics 103, e85.

46. Sturm R \& Datar A (2005) Body mass index in elementary school children, metropolitan area food prices and food outlet density. Public Health 119, 1059-1068.

47. Timperio A, Salmon J, Telford A et al. (2005) Perceptions of local neighbourhood environments and their relationship to childhood overweight and obesity. Int J Obes (Lond) 29 , 170-175.

48. Mushi-Brunt C, Haire-Joshu D, Elliott M et al. (2007) Fruit and vegetable intake and obesity in preadolescent children. Am J Health Educ 38, 258-265. 
49. Gordon-Larsen P, Nelson MC, Page P et al. (2006) Inequality in the built environment underlies key health disparities in physical activity and obesity. Pediatrics 117, 417-424.

50. Centers for Disease Control and Prevention (2011) Behavioral Risk Factor Surveillance System 2010 Summary Data Quality Report. ftp://ftp.cdc.gov/pub/data/brfss/2010_summary_data_ quality_report.pdf (accessed July 2013).

51. Ståhl T, Rütten A, Nutbeam D et al. (2001) The importance of the social environment for physically active lifestyle - results from an international study. Soc Sci Med 52, $1-10$.

52. Catlin TK, Simoes EJ \& Brownson RC (2003) Environmental and policy factors associated with overweight among adults in Missouri. Am J Health Promot 17, 249-258.
53. Boslaugh SE, Luke DA, Brownson RC et al. (2004) Perceptions of neighborhood environment for physical activity: is it "Who you are' or 'Where you live'? J Urban Health 81, 671-681.

54. Housemann RA, Brownson RC, Gonzales GY et al. (2010) REACH 2010 St. Louis Healthy Heart Survey. Unpublished.

55. King AC, Sallis JF, Frank LD et al. (2011) Neighborhood Quality of Life Study for Seniors (SNQLS) Time 2 Survey. http://sallis. ucsd.edu/measure_snqls.html (accessed July 2013).

56. Echeverria SE, Diez-Roux AV \& Link BG (2004) Reliability of self-reported neighborhood characteristics. J Urban Health 81, 682-701.

57. Bickel G, Nord M, Price C et al. (2000) Guide to Measuring Household Food Security, Revised 2000. Alexandria, VA: US Department of Agriculture, Food and Nutrition Service. 